BP ARTUR GRZEGORZ MIZIŃSKI

Wydział Prawa, Prawa Kanonicznego i Administracji

Katolickiego Uniwersytetu Lubelskiego Jana Pawła II

\title{
ADWOKAT - COOPERATOR VERITATIS W PROCESIE O ORZECZENIE NIEWAŻNOŚCI MAŁŻEŃSTWA
}

Treść: Wstęp. - 1. Prawne określenie adwokata. - 2. Publiczna natura procesu o stwierdzenie nieważności małżeństwa. - 3. Zasada poszukiwania prawdy obiektywnej w procesie o stwierdzenie nieważności małżeństwa. - 4. Adwokat współpracownikiem sędziego w poszukiwaniu prawdy obiektywnej na poszczególnych etapach procesu o orzeczenie nieważności małżeństwa. - 4.1. Proces małżeński zwykły przed trybunałem. - 4.2. Proces skrócony przed biskupem. - Zakończenie.

\section{Wstęp}

Małżeństwo między mężczyzną a niewiastą, jako naturalny związek, z woli Bożej cieszy się trwałością i nierozerwalnością oraz jedynością relacji - opuści człowiek ojca i matkę i złączy się ze swoja żona, i będą oboje jednym ciałem (Mt 19,5). Chrystus podkreślając te przymioty w swoim nauczaniu użył słów: co więc Bóg złączył człowiek niech nie rozdziela (Mt 19,6), zobowiązujących do zachowania tej wyjątkowej relacji aż do śmierci. Nie wszystkie celebrowane małżeństwa zostają jednak zawarte ważnie, dlatego też małżonkowie mają prawo do poznania prawdy co do waloru prawnego ich węzła małżeńskiego. Zadaniu temu służą procesy małżeńskie, a w szczególności ten dotyczący orzeczenia o ewentualnej nieważności zawartego małżeństwa. Proces ten, ze względu na jego przedmiot, którym jest sama instytucja węzła małżeńskiego, jest procesem odnoszącym się 
do dobra publicznego. Mając na uwadze dobro wspólne, wszyscy uczestnicy postępowania procesowego, oprócz swoich specyficznych pozycji procesowych i wynikających z nich zadań, zobowiązani są do współpracy z sędzią w celu dotarcia do poznania prawdy obiektywnej. Zadanie to spoczywa również na adwokacie kościelnym, obok obrony interesów prawnych strony, która poprosiła go o pomoc.

\section{Prawne określenie adwokata}

Instytucja adwokata ma bogatą historię, a samo pojęcie „adwokat” ma szerokie znaczenie. Pochodzi ono od łacińskiego słowa advocare - „przywoływać kogoś”, „prosić o radę i pomoc”, „bronić czyjejś sprawy”, „występować przed sądem jako obrońca”, „wezwać obrońcę prawnego”, „wezwać przed sąd”, „mieć kogoś pod opiekąa” . Z reguły mianem adwokata określano obrońcę, szczególnie tego występującego przed sądem.

Kodeksy Prawa Kanonicznego, zarówno poprzedni, jak i obecnie obowiązujący, nie definiują instytucji adwokata kościelnego. Określenie tej instytucji znaleźć można natomiast w pracach licznych kanonistów. U. Huber pisał, że adwokat to znawca prawa, poproszony przez osobę prowadzącą spór, aby ustnie lub pisemnie przedstawić sędziemu sprawę, gotowy popierać ją dowodami i umiejętnie jej bronić, będąc do tego upoważnionym przez odpowiednią władzę zwierzchnią ${ }^{2}$. W ścisłym znaczeniu, według F. Schmalzgruebera, adwokat to człowiek, który w imieniu innej osoby i w jej obecności wnosi prośby, prowadzi obronę i asystuje jej w sądzie poprzez swój autorytet,

\footnotetext{
${ }^{1}$ Por. J. FenRYCH, Rola adwokata w kanonicznym postępowaniu o stwierdzenie nieważności małżeństwa - pierwsze doświadczenia z pracy adwokata kościelnego i funkcjonowania poradni prawno-kanonicznej, w: Orzecznictwo rotalne w praktyce sądowej Kościoła. Materiały z ogólnopolskiego spotkania pracowników sądownictwa kościelnego w Gródku nad Dunajcem w dniach 15-16 czerwca 2009 roku, red. T. Rozkrut, Tarnów 2010, s. 161.

${ }^{2}$ Por. U. Huber, De iure civitatis, Francofurti 1708, s. 608: „Advocatus est vir bonus, iuris peritus, a litigantibus rogatus, ut voce vel scripto causam suam iudici exponat, probet, atque ex arte defendat ad hoc officium publica auctoritate admissus".
} 
radę i działanie ${ }^{3}$. Inni kanoniści mianem adwokata określają znawcę prawa, który służy stronie radą i pouczeniem oraz broni jej przed sądem pisemnie lub ustnie przez naprowadzanie faktów i przytaczanie przepisów prawnych ${ }^{4}$. Współcześnie słowo „adwokat” używane jest jako określenie istniejącej zarówno w systemie prawa kanonicznego, jak i świeckiego instytucji prawnej, oznaczającej prawnika, który udziela porad prawnych oraz broni sprawy klientów w sądzie ${ }^{5}$.

W ściśle prawnym znaczeniu adwokat to osoba posiadająca odpowiednie kwalifikacje i uznana przez kompetentną władzę, poproszona przez stronę procesową o osobistą pomoc (ad auxilium vocatus), polegającą na obronie interesów klienta w procesie lub działaniu w sądzie, charakteryzującym się udzielaniem rad oraz przytaczaniem praw i faktów ustnie bądź pisemnie ${ }^{6}$. Adwokat w sądzie asystuje stronie

${ }^{3}$ Por. F. Schmalzgrueber, Ius ecclesiasticum universum. Brevi method ad discentium utilitatem explicatum seu lucubrationes canonicae in quinque libros decretalium Gregorii IX. Pontificis Maximi, t. 1, pars V, tit. XXXVII, n. 2, Romae 1844, s. 332: „Advocatus (qui alias etiam patronus causae et orator et causidicus appellatur) propter dictus est ille, qui pro altero presente postulat seu defensionem praestat, et ei authoritate, consilio, opera sua in iudicio assistit".

${ }^{4}$ Por. F. X. WERnZ - P. VIDAL, Ius canonicum ad Codicis normam exactum, t. 6 , „De processibus”, Romae 1949, s. 206: „Advocatus vero ecclesiasticus est persona a competente auctoritate ecclesiastica approbata, quae in processibus canonicis iura partium coram iudice ecclesiastico per deductiones iuris et facti scripto traditas vel viva vice prolatas tuetur"; por. także: F. CAppello, Summa iuris canonici, t. 3, Romae 1955, s. 178-179: „Advocatus est persona a competente auctoritate approbata, munus petendi aut postulandi pro partibus in iudicio praestans, per deductionem iuris et factis sive scripto sive viva voce prolatas".

${ }^{5}$ A. G. MizińsKi, Status prawny adwokata w Kościele łacińskim, Lublin 2011, s. 44.

${ }^{6}$ Por. I. Grabowski, Adwokatura w ustawodawstwie kościelnym, Włocławek 1934, s. 3; por. także: R. SzTychmiler, Potrzeba udziału adwokata w procesie o nieważność małżeństwa, Stowarzyszenie Kanonistów Polskich, Biuletyn 6(1994), n. 1, s. 29-30. 
prowadzącej spór $\mathrm{r}^{7}$, jednak nie występuje w jej imieniu ${ }^{8}$. Służy on pomocą stronie w meritum procesu, ale nie podejmuje za nią formalnych czynności procesowych ${ }^{9}$. W sądzie kościelnym adwokat występuje w roli rzecznika strony, a więc rzecznika jej interesu prywatnego. Nie jest on urzędnikiem sądowym i, w odróżnieniu od adwokata w sądzie świeckim, nie zajmuje stanowiska prawnopublicznego ${ }^{10}$. W procesach kanonicznych ta sama osoba może pełnić funkcję zarówno pełnomocnika, jak i adwokata ${ }^{11}$, także w tej samej sprawie.

W Kodeksie Prawa Kanonicznego z 1983 r. na określenie instytucji adwokata, oprócz łacińskiego terminu advocatus, zostały użyte także dwa inne terminy: patronus i defensor. Określenie patronus, czyli obrońca, występuje w kan. $1490^{12}, 1678,1701 \$ 2$ i $1738 \mathrm{KPK} / 83$. W kan. $1481 \$ 3$ w tekście oryginalnym użyto terminu defensor, który, jak

${ }^{7}$ Por. M. Conte a Coronata, Institutiones iuris canonici, t. 3, Taurini 1932, s. 85: "Advocatus est persona quae in iudicio opera et consilio assistit parti litiganti"; F. CAPpello, Summa..., s. 179: „Advocatus distinguitur a procuratore: hic partem repraesentat, ille defendit"; Por. także D. BAtorski, Adwokat, w: Encyklopedia Prawa, Warszawa 1999, s. 8-12.

${ }^{8}$ Por. F. Roberti, De processibus, t. 1, Romae 1926, s. 37: „Advocatus partem non rapraesentat, sed eam comitatur in iudicium, eique praesenti adsistit in recta causae evolutione et praesertim in scripta (c. 1862, 1865) et orali (c. 1866) iuridica defensione".

${ }^{9}$ Por. R. Sztychmiler, Potrzeba udziału adwokata..., s. 30.

${ }^{10}$ Por. F. Bączkowicz, J. Baron, W. Stawinoga, Prawo kanoniczne. Podręcznik dla duchowieństwa, t. 3, Opole 1958, s. 62; V. Andriano, Avvocati e procuratori nell'ordinamento canonico, w: AA.VV., I giudizi nella Chiesa. Il processo contenzioso e il processo matrimoniale, Milano 1998, s. 127-149. Aczkolwiek kanon 1490 Kodeksu Prawa Kanonicznego z 1983 r. traktuje o urzędzie obrońcy stałego, który jest pracownikiem trybunału kościelnego, wynagradzanym przez ten sąd.

${ }^{11}$ Por. I. Gordon, Nowy proces nieważności matżeństwa. Postępowanie, komentarze, tłum. J. Walicki, Częstochowa 1984, s. 11.

${ }^{12}$ Codex Iuris Canonici auctoritate Ioannis Pauli PP. II promulgatus, AAS 75 II(1983), s. 137, Kodeks Prawa Kanonicznego przekład polski zatwierdzony przez Konferencję Episkopatu, Poznań 1984, (dalej skrót: KPK/83), kan. 1490: „In unoquoque tribunali, quatenus fieri possit, stabiles patroni constituantur, ab ipso tribunali stipendium recipientes, qui munus advocati vel procuratoris in causis praesertim matrimonialibus pro partibus quae eos seligere malint, exerceant". 
wynika z sensu normy, również oznacza obrońcę, co zostało oddane w polskim tłumaczeniu kanonu. Wśród kanonistów można odnaleźć odmienne opinie co do interpretacji tych łacińskich terminów ${ }^{13}$. Należy podkreślić, że w Instrukcji Dignitas Connubii ${ }^{14}$ z 2005 roku nie stosuje się zamiennie terminów patronus i advocatus. Wszędzie tam, gdzie mowa jest o instytucji adwokata, w tekście łacińskim prawodawca kościelny stosuje termin advocatus. Nawet w art. $113 \$ 3$, odpowiadającemu kan. 1490 KPK/83, użyte w Kodeksie określenie patroni zostało zastąpione terminem advocati ${ }^{15}$.

Zadanie adwokata i pełnomocnika w przepisach Kościoła łacińskiego zostało określone łacińskim terminem munus oraz officium o charakterze kościelnym. Pozostaje ono zawsze w służbie Kościoła i jest ukierunkowane na jego cel najwyższy, czyli zbawienie dusz. O instytucji adwokata można mówić w szerokim ujęciu jako o wolnym zawodzie, ze specyficznymi dla siebie prawami, ale zawsze z uwzględnieniem ducha i celów własnych kanonicznego porządku prawnego. W tym duchu adwokat, podobnie jak pozostałe podmioty procesu, zobowiązany jest do współpracy z sędzią w realizacji fundamentalnego celu postępowania kanonicznego, jakim jest poszukiwanie prawdy obiektywnej ${ }^{16}$.

„W celu ważnego sprawowania urzędu, officium adwokata nie jest konieczne, aby podmiot był ordinatus in sacris ${ }^{17}$ lub uczestniczył

${ }^{13}$ J. Ochoa twierdzi, że termin patronus (obrońca) jest określeniem zbiorczym, oznaczającym tak pełnomocnika, jak i adwokata. Inaczej w tej kwestii wypowiada się Lüdicke. Por. J. OсноA, La figura canónica del procurador y abogado publico, w: Dilexit iustitiam. Studia in honorem Aurelii Card. Sabattani, red. Z. Grocholewski, V. Cárcel Ortí, Città del Vaticano 1984, s. 261; K. LüDICKE Kommentar zu can. 1481, w: Münsterischer Kommentar zum CIC, t. 6, red. K. Lüdicke, Essen 1984-, vor 1481/2.

${ }^{14}$ Pontificio Consiglio Per I Testi Legislativi, Dignitas Connubii. Istruzione da osservarsi nei tribunali diocesani e interdiocesani nella trattazione delle cause di nullità del matrimonio, Città del Vaticano, 2005, dalej DC.

${ }^{15}$ Por. DC, s. 95-96. W KPK/83, kan. 1490 znajdujemy przepis: stabiles patroni constituantur, który w Instrukcji został zastąpiony przepisem - stabiles advocati constituantur.

${ }^{16}$ Por. A. G. Mizıński, Status prawny adwokata..., s. 122.

${ }^{17}$ Por. KPK/83, kan. $274 \$ 1$. 
$\mathrm{w}$ wykonywaniu potestatis iurisdictionis ${ }^{18}$. Stąd adwokatura, nawet jeśli widziana jako ministero ecclesiale, jest i pozostanie zawodem, który według będących w mocy przepisów nie stanowi i nigdy nie będzie mógł stanowić części struktury organizacyjnej urzędów kościelnych wymagających do ich wykonywania potestatis ordinis i potestatis iurisdictionis" ${ }^{\prime 9}$. Do urzędu adwokata nie mają więc zastosowania przepisy, które domagają się od tytulariusza uczestnictwa w sprawowaniu władzy rządzenia ani władzy sądowniczej ${ }^{20}$. Zgodnie $\mathrm{z}$ kanonem 1483, adwokat musi być zatwierdzony przez biskupa diecezjalnego, co jest spowodowane istnieniem w Kościele ścisłego powiązania pomiędzy władzą sądowniczą a władzą dyscyplinarną i administracyjną, które, rozumiane w sensie szerokim, dotyczą także adwokatów zobowiązanych na mocy prawa do podporządkowania się sprawowanej przez biskupa władzy czuwania oraz jego władzy decyzyjnej $^{21}$.

Inaczej przedstawia się, określona w kan. $1490 \mathrm{KPK} / 83$, sprawa urzędu adwokata stałego. Patronus stabilis jawi się bowiem jako urząd ustanowiony na stałe przy każdym trybunale, jeżeli tylko jest to możliwe. Tytulariusz tego urzędu otrzymuje nominację od właściwej władzy kościelnej, podobnie jak inni pracownicy sądu. Inna jest także - w porównaniu $\mathrm{z}$ adwokatem prywatnym - jego zależność administracyjna od sądu, w którym pracuje. Tak uregulowana pozycja formalno-prawna adwokata stałego nie zmienia jednak tego, co należy do istoty jego posługi, gdyż zawsze występuje on jako obrońca strony, niezależnie od tego czy został wybrany przez stronę, czy też wyznaczony z urzędu. Tak więc niezależnie od tego czy adwokat występuje w roli prywatnego czy stałego, zawsze spełnia on swój munus - officium, do istoty którego należy występowanie w czasie

\footnotetext{
${ }^{18}$ Por. KPK/83, kan. $129 \$ 2$.

${ }^{19}$ A. G. MizıŃski, Status prawny adwokata..., s. 122.

${ }^{20}$ Por. KPK/83, kan. $135 \$ 3$.

${ }^{21}$ Por. S. Villeggiante, L'Avvocato del foro ecclesiastico ed i poteri disciplinari del giudice nelle cause di nullità matrimoniale, Monitor Ecclesiasticus 122(1997), s. 554-555.
} 
procesu obok strony, nie zaś w jej zastępstwie, świadcząc jej zawsze i tylko obronę oraz pomoc prawną ${ }^{22}$.

Prawodawca w kan. 1483 KPK/83 określa wymogi, które powinien spełniać adwokat kościelny. Powinien on być osobą pełnoletnią odznaczającą się nienaruszoną sławą i dobrą opinią (bonae famae $)^{23}$. Cechy te są tożsame $\mathrm{z}$ wymaganiami stawianymi pełnomocnikom. Adwokat kościelny co do zasady powinien być katolikiem, jednak w wyjątkowych sytuacjach biskup moderator trybunału może zezwolić na obronę niekatolikowi. Kolejnym wymogiem w stosunku do adwokata jest posiadanie stopnia doktora lub przynajmniej biegłość w dziedzinie prawa kanonicznego potwierdzona przez tegoż biskupa na podstawie przedłożonych mu dokumentów. Ostatnim warunkiem niezbędnym do wykonywania zadań adwokata jest uzyskanie zatwierdzenia przez biskupa moderatora trybunału, przy którym adwokat ma pełnić swoje zadania ${ }^{24}$.

\section{Publiczna natura procesu o stwierdzenie nieważności małżeństwa}

Wśród spraw rozpatrywanych przez sądy kościelne wyróżnia się sprawy dotyczące dobra prywatnego oraz sprawy o charakterze publicznym, mające na celu ochronę dobra publicznego Kościoła ${ }^{25}$. Wyrazem szczególnej troski o to dobro, prawo Kościoła i interesy wspólnoty są przepisy, instytucje i urzędy ustanawiane dla jego ochrony ${ }^{26}$. Takim urzędem jest na przykład urząd rzecznika sprawiedliwości ${ }^{27}$ oraz występujący w celu ochrony sakramentu święceń

\footnotetext{
${ }^{22}$ Por. A. G. Miziński, Status prawny adwokata..., s. 123.

${ }^{23}$ Por. KPK/17, kan. 1657 \$1; KPK/83, kan. 1483.

${ }^{24}$ Por. DC, art. $105 \$ 1$.

${ }^{25}$ KPK/83, kan. 1452; por. M. Greszata-Telusiewicz, Pelnomocnicy procesowi $i$ adwokaci; aktywność stron w procesie; etapy postępowania sądowego oraz relacje prawne powstające podczas procesu ( $Z$ rozważań nad kanonicznym procesem zwyczajnym - część VI), Człowiek - Rodzina - Prawo 7(2013), s. 19.

${ }^{26}$ Por. A. G. Miziński, Status prawny adwokata..., s. 315-317.

${ }^{27}$ Por. KPK/83, kan. 1430, 1431.
} 
i sakramentu małżeństwa urząd obrońcy węzła ${ }^{28}$. Również podejmowanie przez sędziego działań ex officio, które zasadniczo jest zabronione, w sprawach karnych oraz w innych sprawach dotyczących dobra publicznego lub zbawienia dusz, jest dopuszczone, a nawet zalecane, iudex procedere potest et debet etiam ex officio ${ }^{29}$. Ponadto w sprawach karnych oraz w sprawach spornych, jeżeli chodzi o małoletnich albo o proces dotyczący dobra publicznego, jeśli strona nie posiada obrońcy, sędzia powinien go mianować z urzędu ${ }^{30}$. Wyjątkiem są tu jednak sprawy małżeńskie, w których, mimo zaliczania ich do spraw spornych dotyczących dobra publicznego, nie występuje obowiązek udziału obrońcy z urzędu, a jedynie możliwość ustanowienia go $\mathrm{z}$ woli strony ${ }^{31}$ lub z nakazu sędziego w sprawach, które uzna za szczególnie trudne ${ }^{32}$.

Jeśli chodzi o przepisy dotyczące spraw o orzeczenie nieważności małżeństwa, zostały one uregulowane w Liście Apostolskim motu proprio Mitis Iudex Dominus Iesus, reformującym kanony Kodeksu Prawa Kanonicznego dotyczące spraw o orzeczenie nieważności małżeństwa ${ }^{33}$. Zastąpiły one przepisy zawarte w KPK/83, księdze VII, części III, rozdziale I zatytułowanym De causis ad matrimonii nullitatem

\footnotetext{
${ }^{28}$ Por. KPK/83, kan. 1432; R. Coppola, Pubblico e privato, w: Il giudizio di nullità matrimoniale dopo l'istruzione «Dignitas connubii». Parte prima: i principi, red. P. A. Bonnet, C. Gullo, Città del Vaticano 2007, s. 322; V. PAlestro, Il difensore del vincolo ed il promotore di giustizia (artt. 53-60), w: Il giudizio di nullità matrimoniale dopo l'istruzione «Dignitas connubii». Parte seconda: la parte statica del processo, red. P. A. Bonnet, C. Gullo, Città del Vaticano 2007, s. 185.

${ }^{29}$ Por. KPK/83, kan. 1452 \$1; R. Coppola, Pubblico e privato, s. 333-334.

${ }^{30}$ Por. KPK/83, kan. $1481 \S 3$.

${ }^{31}$ Por. KPK/83, kan. 1481; kan. 1490.

${ }^{32}$ Por. KPK/83, kan. $1481 \$ 1$; DC, art. $101 \$ 2$.

33 „To wszystko starannie rozważywszy, ogłaszam i postanawiam, że Księga VII Kodeksu Prawa Kanonicznego, Część III, Tytuł I, Rozdział I Sprawy o orzeczenie nieważności małżeństwa (kan. 1671-1691), z dniem 8 grudnia 2015 roku zostaje w całości zastąpiona...", Franciszek, List apostolski motu proprio Mitis Iudex Dominus Iesus, reformujący kanony Kodeksu Prawa Kanonicznego dotyczące spraw o orzeczenie nieważności małżeństwa. List apostolski motu proprio Mitis et Misericors Iesus, reformujący kanony Kodeksu Kanonów Kościołów Wschodnich dotyczące
} 
declarandam. W kwestiach nieuregulowanych w sposób odrębny, o ile nie sprzeciwia się temu natura rzeczy, stosuje się kanony o procesie w ogólności i o zwyczajnym procesie spornym, z zachowaniem norm specjalnych co do spraw o stanie osób oraz spraw odnoszących się do dobra publicznego ${ }^{34}$.

W zwyczajnym procesie spornym zastosowanie ma zasada dyspozycyjności, zgodnie $\mathrm{z}$ którą $\mathrm{w}$ sprawach dotyczących dobra prywatnego sędzia może działać tylko na prośbę strony. W niektórych jednak sytuacjach, by uniknąć niesprawiedliwego wyroku, przewidziana jest możliwość działania sędziego z urzędu, co jest przejawem zastosowania zasady „inkwizycyjności czyli oficjalności” ${ }^{35}$. W myśl tej ostatniej, w procesach dotyczących stwierdzenia nieważności małżeństwa, które odnoszą się do dobra publicznego, sędzia po wprowadzeniu sprawy, ze względu na najwyższe dobro, którym jest zbawienie dusz, może także działać ex officio. Zgodnie z przepisami prawa może on w ten sposób podjąć następujące czynności: „sprawdzenie właściwości trybunału przed przyjęciem sprawy; zbadanie zdolności stron do występowania w procesie; sprawdzenie, czy są spełnione warunki przyjęcia skargi; orzeczenie nieważności czynności, które są nieważne, jeśli wymaga tego dobro publiczne; uchylenie lub poprawienie $z$ urzędu dekretu lub wyroku przedstanowczego przed zakończeniem sprawy głównej; ustalenie kosztów procesowych bez wniosku strony; aktywna współpraca w prowadzeniu i ochronie procesu"36. Tak więc proces o stwierdzenie nieważności małżeństwa łączy w sobie z jednej strony zasadę dyspozycyjności, jak każdy proces sporny, z drugiej zaś strony, ze względu na małżeństwo jako dobro publiczne Kościoła, zawiera cały szereg elementów oficjalności, bez których nie byłyby możliwe dotarcie do prawdy obiektywnej i ochrona węzła małżeńskiego ${ }^{37}$.

spraw o orzeczenie nieważności małżeństwa (tekst łacińsko-polski), Tarnów 2015, s. 15.

${ }^{34}$ Por. tamże, s. 31.

${ }^{35}$ M. Greszata-Telusiewicz, Nałożenie klauzuli sądowej $w$ relacji do zasady dyspozycyjności i inkwizycyjności, Człowiek - Rodzina - Prawo 7(2013), s. 11.

${ }^{36}$ Tamże, s. 11.

${ }^{37}$ Por. tamże, s. 12. 
Wyrazem ochrony dobra publicznego Kościoła jest również ustanowienie przez prawodawcę kościelnego domniemania prawnego za ważnością małżeństwa. W wątpliwości zatem, dopóki nie udowodni się czegoś przeciwnego, małżeństwo należy uważać za ważne ${ }^{38}$. Podmiotami uprawnionymi do zaskarżania małżeństwa są małżonkowie, jednak w sytuacjach, gdy nieważność małżeństwa została już rozgłoszona, zgodnie $\mathrm{z}$ kan. $1674 \$ 1 \mathrm{Listu}$ apostolskiego motu proprio Mitis Iudex Dominus Iesus papieża Franciszka, proces może zostać wszczęty także z urzędu przez rzecznika sprawiedliwości ${ }^{39}$.

Publicznej naturze małżeństwa i prawa małżeńskiego materialnego odpowiada publiczna natura procesu o stwierdzenie nieważności małżeństwa. Kościół bowiem stojąc na staży dobra publicznego, jakim jest węzeł małżeński, otacza go szczególną troską tak duszpasterską, jak i prawną. Publicznej natury procesu o stwierdzenie nieważności małżeństwa żadną miarą nie zmienia nowa regulacja zawarta w motu proprio Mitis Iudex Dominus Iesus, nawet jeśli nie wymaga ona trybunału kolegialnego, podwójnego wyroku zgodnego i w określonych warunkach przewiduje proces małżeński skrócony przed biskupem. Ten ostatni może mieć miejsce „w przypadkach, w których skarga o nieważność małżeństwa jest poparta szczególnie oczywistymi argumentami” ${ }^{40}$. Nowe przepisy regulujące proces „nie mają na celu promowania nieważności małżeństwa, ale przyspieszenie procesów, jak również ich uproszczenie w taki sposób, aby serca wiernych, którzy oczekują na wyjaśnienie swojej sytuacji, nie były zbyt długo zniewolone przez mroki wątpliwości z powodu opóźnień

\footnotetext{
${ }^{38}$ Por. KPK/83, kan. 1060, A. DzIĘGA, Strony sporu w kanonicznym procesie o nieważność małżeństwa, Warszawa 1994, s. 144-145.

${ }^{39}$ Por. Franciszek, Mitis Iudex Dominus Iesus, s. 19, kan. 1674 \$1; J. GręźLIKowski, Urząd promotora sprawiedliwości w obowiązujących przepisach prawa kanonicznego, Studia Włocławskie 10(2007), s. 314; R. Coppola, Pubblico e privato, s. 322; V. Palestro, Il difensore del vincolo..., s. 184-185.

${ }^{40}$ Franciszek, Mitis Iudex Dominus Iesus, s. 13.
} 
w wydaniu wyroku" ${ }^{41}$. Z drugiej zaś strony takie uproszczenie procedury nie narusza w niczym „ochrony prawdy świętego węzła”42.

Prawna ochrona węzła małżeńskiego domaga się poznania prawdy co do jego ewentualnej nieważności. Zadaniu temu służą wyżej przytoczone przepisy dotyczące procesu o stwierdzenie nieważności małżeństwa. Wśród nich w szczególności te, które określają poszczególne zadania stron i innych podmiotów biorących udział w procesie. Nie do przecenienia jest posługa adwokata, który jako osoba kompetentna zachowa należną równowagę pomiędzy ochroną interesów strony, której jest obrońcą a obowiązkiem dotarcia do poznania prawdy obiektywnej na temat przedmiotu sporu, którym jest nieważność węzła małżeńskiego.

\section{Zasada poszukiwania prawdy obiektywnej w procesie o stwierdzenie nieważności małżeństwa}

Celem procesu o orzeczenie nieważności małżeństwa jest ustalenie prawdy obiektywnej, która musi być - jak stwierdził św. Jan Paweł II „fundamentem, matką i prawem sprawiedliwości”"43. Strona, wnioskując o ustalenie prawdy materialnej o istnieniu lub nieistnieniu węzła małżeńskiego, która determinuje jej pozycję kanoniczną, wnosi tym samym o ustalenie prawdy dotyczącej faktu eklezjalnego ${ }^{44}$. Prawda

\footnotetext{
${ }^{41}$ Tamże, s. 9-11.

42 Tamże, s. 11.

${ }^{43}$ Joannes Paulus II, Allocutio ad Tribunalis Sacrae Romanae Rotae Decanum, Praelatos Auditores, Officiales et Advocatos, novo litibus iudicandis ineunte anno: de veritate iustitia matre, 04.02.1980, AAS 72(1980), s. 173. Por. JoAnnes PAulus II, Allocutio ad Romanae Rotae iudices administros coram admissos, 28.01.1994, AAS 86(1994), s. 947-952. Por. także Z. Grocholewski, Zmiany w kanonicznym prawie procesowym, KiP 7(1990), s. 91; T. Rozkrut, Jan Paweł II do Roty Rzymskiej (19172003), Tarnów 2003, s. 75.

${ }^{44}$ Por. W. GóRALSKI, Natura procesów o nieważność małżenstwa oraz zadania trybunału w ich prowadzeniu. Papież Jan Paweł II do Roty Rzymskiej 22 I 1996 r., Jus Matrimoniale 2/8(1997), s. 88-91; R. SoBAŃsкI, Udział adwokata w procesie o nieważność małżństwa, Jus Matrimoniale 2/8(1997), s. 130; W. GóRALSKI, Rola adwokata $w$ kościelnych procesach matżeńskich $w$ świetle KPK $z 1983$ roku oraz
} 
obiektywna jest rozpoznaniem faktycznego stanu rzeczy determinującego fakty prawne ${ }^{45}$.

Papież Benedykt XVI w swoim pierwszym przemówieniu rotalnym w 2006 r. podkreślił, że proces o nieważność małżeństwa nie jest skierowany przeciwko drugiej stronie. Przedmiotem tego procesu jest deklaracja prawdy na temat ewentualnej nieważności konkretnego węzła ${ }^{46}$. W tego rodzaju procesie nie sądzi się stron, lecz docieka prawdy obiektywnej zachodzącej w chwili zawierania małżeństwa, prawdy o małżeństwie ${ }^{47}$. Od początku procesu aż do wydania wyroku prawda musi być zawsze fundamentem, a jej poszukiwanie musi być zawsze zgodne z prawem ${ }^{48}$.

Do poszukiwania prawdy zobowiązany jest nie tylko sędzia ${ }^{49}$, ale także każdy uczestnik procesu ${ }^{50}$. Zadaniem wszystkich osób zaangażowanych w kanoniczny proces o nieważność małżeństwa jest więc

instrukcji Dignitas connubii, w: W. Góralski, Studia nad małżeństwem i rodzina, Warszawa 2007, s. 552.

${ }^{45}$ Por. A. DzIęGa, Zasada poszukiwania prawdy obiektywnej w procesie kanonicznym, w: Kościelne Prawo Procesowe. Prawo Rodzinne. Materiały i Studia, t. IV, red. A. Dzięga, M. Greszata-Telusiewicz, Z. Jancewicz, P. Telusiewicz, Lublin 2007, s. 174 .

${ }^{46}$ Por. Benedictus XVI, Ad Tribunal Rotae Romanae, AAS 2006(2), s. 135; JoAnNes Paulus II, Allocutio ad Tribunalis Sacrae Romanae Rotae Decanum, Praelatos Auditores, s. 174-178; Joannes Paulus II, Allocutio ad Sacrae Romanae Rotae Tribunalis Praelatos Auditores, Officiales et Advocatos coram admissos, 28.01.1982, AAS 74(1982), s. 449-454. Por. także R. SobAŃsKi, Iudex veritatem de matrimonio dicit, Jus Matrimoniale 4(1999), s. 186; T. Rozkrut, Ochrona sq̨dowa praw wiernych - szczegółowe zagadnienia wybrane, w: 25-lecie promulgacji Kodeksu Prawa Kanonicznego. Obowiązywanie i stosowanie w Polsce, red. J. Krukowski, Z. Tracz, Łódź 2009, s. 116.

${ }^{47}$ Por. R. Sobański, Ochrona małżeństwa w kanonicznym prawie procesowym, Prawo Kanoniczne 52(2009) nr 3-4, s. 165, 167.

${ }^{48}$ Por. S. Pikus, Niezawisłość sędziego kościelnego, Lublin-Sandomierz 2009, s. 178.

${ }^{49}$ Por. KPK/83, kan. 1452, 1608. Por. także CCEO, kan. 1110, 1291. Na ten temat także Joannes Paulus II, Allocutio ad Romanae Rotae tribunal, 29.01.2004, AAS 96(2004), s. 348-352.

${ }^{50}$ Por. S. Pikus, Niezawisłość sędziego kościelnego, s. 181. 
prowadzenie działań w kierunku rei veritate ${ }^{51}$. W służbie prawdy i dobra dusz współdziałają, niczym w jednym organizmie, sędziowie, obrońca węzła i adwokat, odgrywając wzajemnie skoordynowane role, których nie wolno mieszać ani zamazywać ${ }^{22}$. Poszukiwanie prawdy obiektywnej domaga się także zachowania norm kanonicznych ${ }^{53}$.

Pierwszym odpowiedzialnym za poszukiwanie prawdy obiektywnej w postepowaniu procesowym jest sędzia kościelny ${ }^{54}$, na którym spoczywa szereg obowiązków, a przede wszystkim wierność $\mathrm{w}$ przestrzeganiu prawa Bożego naturalnego i pozytywnego oraz kanonicznego ${ }^{55}$. O działaniach podejmowanych w celu dotarcia do prawdy przez sędziego jest mowa m. in. w kanonach 1530, 1532, 1548, 1562 KPK/83, a także w art. 65, 122, 167, 177 Instrukcji Dignitas connubii. Jeszcze przed przyjęciem sprawy sędzia jest zobowiązany do zachęcenia małżonków do szczerej współpracy w poszukiwaniu prawdy obiektywnej ${ }^{56}$.

W trakcie trwania procesu poszukiwaniu prawdy materialnej służy prawo sędziego do żądania od stron złożenia przysięgi, „że będą mówiły prawdę, chyba że poważna przyczyna sugeruje coś innego" 57 . Podobnie w odniesieniu do świadków biorących udział w procesie sędzia powinien pouczyć świadka o celu składanych zeznań oraz

\footnotetext{
${ }^{51}$ Por. R. SobańsKi, Iudex veritatem de matrimonio..., s. 196.

${ }^{52}$ Por. R. SobAŃsKi, Udział adwokata..., s. 131-132.

${ }^{53}$ Por. Joannes Paulus II, Allocutio ad Tribunal Romanae Rotae iudiciali ineunte anno, 29.01.2005, AAS 97(2005), s. 164-166, Por. także G. Leszczý́ski, Prawo do obrony w przemówieniach Jana Pawła II do Roty Rzymskiej, Jus Matrimoniale 13/19(2008), s. 105.

${ }^{54} \mathrm{~W}$ procesie skróconym biskup diecezjalny. Por. Franciszek, Mitis Iudex Dominus Iesus, s. 27, kan. 1683.

${ }^{55}$ Por. Joannes Paulus II, Ad Tribunalis Sacrae Romanae Rotae Decanum, s. 173, n. 1; W. KRAIŃsKI, Querela nullitatis w procesie małżeńskim według przepisów procesowych Kościoła łacińskiego, Roczniki Nauk Prawnych, t. XX, nr 2(2010), s. 172.

${ }^{56}$ Por. DC, art. 65; W. KIwIor, Zasady działania sąów, w: Komentarz do Instrukcji procesowej «Dignitas connubii», red. T. Rozkrut, Sandomierz 2007, s. 123-125, art. 65.

${ }^{57}$ KPK/83, kan. 1532.
} 
przypomnieć mu o obowiązku mówienia tylko prawdy ${ }^{58}$. Sędzia ma również obowiązek zadbania o to, aby postępowanie odbywało się zgodnie z prawem, by wszystko co istotne dla sprawy zostało odpowiednio zaprotokołowane a żadna ze stron nie została pozbawiona swoich praw i uprawnień w dochodzeniu do prawdy.

W literaturze kanonistycznej podkreśla się, że udział adwokata w sprawie o orzeczenie nieważności małżeństwa stanowi równowagę dla obrońcy węzła małżeńskiego ${ }^{59}$. Obrońca węzła i adwokat stają na odmiennych pozycjach wyjściowych: jeden pro vinculo, drugi pro nullitate, ale obydwaj salva semper veritate ${ }^{60}$. Nie powinno istnieć między nimi współzawodnictwo zmierzające do osiągnięcia własnego celu, jakim jest wygranie sprawy ${ }^{61}$.

Urząd obrońcy węzła jest jednym z gwarantów dotarcia do prawdy obiektywnej, a jego obecność w sprawach o nieważność małżeństwa jest zawsze konieczna ${ }^{62}$. Jego zadaniem jest wskazanie tych wszystkich argumentów, które świadczą przeciwko nieważności małżeństwa lub jego rozwiązaniu. Ma on obowiązek proponować i przedstawiać omnia, czyli wszystko to, co przemawia za tym, aby małżeństwo nie zostało uznane za nieważne ${ }^{63}$. Zgodnie $\mathrm{z}$ normami kodeksowymi i późniejszymi regulacjami dotyczącymi procesu o stwierdzenie nieważności małżeństwa ${ }^{64}$ obrońca węzła powinien się angażować w proces od samego początku oraz w czasie jego trwania. W każ-

${ }^{58}$ Por. R. Sztychmiler, Podmioty obowiązku ustalenia prawdy $w$ procesie o nieważność małżeństwa, w: Współpraca sądów ze stronami procesowymi i adwokatami, red. R. Sztychmiler, J. Krzywkowska, Olsztyn 2011, s. 82.

${ }^{59}$ Por. C. Gullo, Procuradores y abogados (cann. 1483-1490), w: Comentario Exegético al Código de Derecho Canónico, t. IV/1, red. Á. Marzoa - J. Miras R. Rodríguez - Ocaña, Pamplona 2002, s. 1065.

${ }^{60}$ Por. R. SoвAŃsкi, Udział adwokata $w$ procesie..., s. 131; W. GórAlsKi, Rola i zadania adwokata w procesach kanonicznych w alokucjach papieży do Roty Rzymskiej (1939-2007), Prawo Kanoniczne 50(2007) nr 3-4, s. 111; S. Pikus, Niezawisłość sędziego kościelnego, s. 181.

${ }^{61}$ Por. J. Torre, Processus matrimonialis, Neapoli 1956, s. 127-171.

${ }^{62}$ Por. DC, art. $56 \$ 1$.

${ }^{63}$ Por. A. DzIĘGa, Zasada poszukiwania prawdy obiektywnej, s. 175-183.

${ }^{64}$ DC; Franciszer, Mitis Iudex Dominus Iesus. 
dym stadium procesu, szczególnie na etapie dyskusji sprawy, gdzie jest zobowiązany do napisania uwag przedwyrokowych, winien on przedstawiać sprzeciwy i zarzuty, a także dowody, mogące przyczynić się do obrony węzła, nigdy jednak nie może działać w celu udowodnienia nieważności węzła małżeńskiego ${ }^{65}$. Posługa obrońcy węzła jest więc posługą na rzecz prawdy obiektywnej ${ }^{66}$. Znaczenie tej posługi jeszcze bardziej wzrosło wraz z wprowadzeniem przepisów określających nową procedurę procesu o stwierdzenie nieważności małżeństwa.

Podobne uprawnienia posiada, stojący najczęściej na przeciwnej pozycji w stosunku do obrońcy węzła, adwokat strony. Musi on być świadomy swego obowiązku poszukiwania prawdy ${ }^{67}$ i ochrony godności małżeństwa ${ }^{68}$. Służąc fachową pomocą ma on za zadanie wykazać wszystkie fakty, które przemawiają za nieważnością lub ważnością małżeństwa, w zależności od tego jakie zlecenie uzyskał od swojego mocodawcy ${ }^{69}$. Adwokat powinien wprawdzie działać w interesie strony, ale nie za wszelką cenę. Chociaż motywem jego działania jest „prawda strony”, to nade wszystko pozostaje on w służbie obiektywnej prawdy materialnej ${ }^{70}$. Jego obowiązkiem jest również pouczenie strony, gdyby tego nie wiedziała, że w dążeniu do osiągnięcia określonego celu winna działać w zgodzie z prawem i prawdą ${ }^{71}$. Ponadto adwokat powinien reprezentować swojego klienta $\mathrm{w}$ taki

${ }^{65}$ Por. R. Sztychmiler, Podmioty obowiązku ustalenia prawdy..., s. 90; DC, art. $56 \$ 2-3 ; \mathrm{KPK} / 83$, kan. 1432; W. GóRALSKI, Urząd obrońcy węzła małżéskiego w świetle przemówień papieży do Roty Rzymskiej z lat 1939-2007, Jus Matrimoniale 13/19(2008), s. 87.

${ }^{66}$ Por. A. DzIĘGA, Zasada poszukiwania prawdy obiektywnej, s. 175.

${ }^{67}$ Por. W. GóRAlski, Rola i zadania adwokata..., s. 113.

${ }^{68}$ Por. C. Gullo, L'assetto della professione forense canonica, w: AA.VV., Il diritto di difesa nel processo matrimoniale canonico, Città del Vaticano 2006, s. 118.

${ }^{69}$ Por. R. Sztrchmiler, Podmioty obowiązku ustalenia prawdy..., s. 90.

${ }^{70}$ Por. R. SobAŃski, Udział adwokata w procesie..., s. 132.

${ }^{71}$ Por. R. Sztychmiler, Adwokat w procesie o nieważność małżeństwa, w: Proces małżeński w świetle «Dignitas connubii» - pierwsze doświadczenia. Materiały z ogólnopolskiego spotkania pracowników sądownictwa kościelnego w Gródku nad Dunajcem w dniach 11-12 czerwca 2007. III Ogólnopolskie Forum Sądowe”, red. T. Rozkrut, Tarnów 2008, s. 107-112. 
sposób, aby nie było wątpliwości co do jego uczciwości, mając zawsze na pierwszym miejscu prawdę i sprawiedliwość ${ }^{72}$. Adwokat współtworzy sprawiedliwość, dlatego musi posiadać etyczne przygotowanie do sprawowania tego zadania ${ }^{73}$. Świadomość tego celu powinna chronić go przed posługiwaniem się kłamstwem, nakłanianiem stron i świadków do składania fałszywych zeznań oraz podejmowaniem innych niegodziwych działań ${ }^{74}$.

Do współpracy w dotarciu do prawdy zobowiązane są również strony procesu poprzez aktywny udział w czynnościach procesowych $^{75}$. Prawodawca kodeksowy zobowiązuje strony do udzielania odpowiedzi na pytania sędziego i ujawnienia całej prawdy ${ }^{76}$. Wzmocnieniem tego obowiązku jest przysięga składana wobec sędziego ${ }^{77}$. W sytuacji kiedy powód inicjuje proces domniemuje się, że jest on moralnie przekonany o prawdziwości swojego twierdzenia oraz chce dotrzeć do owej prawdy. Strona pozwana natomiast w czasie trwania procesu ma prawo nie angażować się $\mathrm{w}$ działania zmierzające do poznania prawdy, jednak pomimo swojej biernej postawy powinna odpowiadać na zadane pytania ${ }^{78}$. Gdyby strona pozwana nie chciała odpowiadać, sędzia ma prawo do roztropnej oceny takiego postępowania według własnego doświadczenia i sumienia w celu wyciągnięcia wniosku w odniesieniu do udowodnienia faktów ${ }^{79}$.

${ }^{72}$ Por. A. G. Miziński, Adwokat gwarantem prawa do obrony w procesie kanonicznym, w: Urzędy sądowe - władza i służba. Materiały z ogólnopolskiego spotkania pracowników sądownictwa kościelnego w Gródku nad Dunajcem w dniach 11-12 października 2004 roku", red. T. Rozkrut, Tarnów 2005, s. 52.

${ }^{73}$ Por. M. Greszata, Iudicium cum principiis. Kodeksowa weryfikacja wybranych zasad prawa procesowego w kanonicznych sprawach o nieważność matżeństwa, Lublin 2008, s. 237.

${ }^{74}$ Por. W. Gór ALSKi, Rola i zadania adwokata..., s. 111.

${ }^{75}$ Por. R. Sztychmiler, Podmioty obowiązku ustalenia prawdy..., s. 85.

${ }^{76}$ Por. KPK/83, kan. $1531 \$ 1$.

${ }^{77}$ Por. KPK/83, kan. 1532; DC, art. $95 \$ 1$.

${ }^{78}$ Por. A. DzIĘGA, Zasada poszukiwania prawdy obiektywnej, s. 177.

${ }^{79}$ Por. KPK/83, kan. 1531 \$2; R. SzTychmiler, Podmioty obowiązku ustalenia prawdy..., s. 86. 
W sprawach dotyczących węzła małżeńskiego może również wyjątkowo występować rzecznik sprawiedliwości. Może on zaskarżyć małżeństwo kiedy jego nieważność została już rozgłoszona, a jego uważnienie nie jest możliwe ${ }^{80}$. W innych sytuacjach jego obecność jest uzasadniona tylko wtedy, kiedy biskup diecezjalny uzna, że w związku z daną sprawą może zostać zagrożone dobro publiczne ${ }^{81}$. W tym ostatnim przypadku rola rzecznika sprowadza się do nadzorowania przebiegu procesu zgodnie z przepisami prawa ${ }^{82}$.

W szczególnych przypadkach odkrycie prawdy odnośnie do nieważności małżeństwa wymaga opinii biegłego. Jest on rzeczoznawcą kwalifikowanym, czyli ekspertem, który dzięki posiadanej wiedzy fachowej $z$ danej dziedziny może wydać na potrzeby procesu opinię ${ }^{83}$. „Z pomocy biegłych należy skorzystać, ilekroć na podstawie nakazu prawa lub sędziego jest konieczne ich przesłuchanie i opinia, oparte na doświadczeniu lub wiedzy, dla potwierdzenia jakiegoś faktu lub poznania prawdziwej natury jakiejś rzeczy" ${ }^{\prime 4}$. W procesach małżeńskich z nakazu prawa udział biegłego wymagany jest „w sprawach dotyczących impotencji lub braku zgody spowodowanej chorobą umysłową lub anomalią natury psychicznej" ${ }^{85}$. W takich przypadkach sędzia zobowiązany jest do skorzystania z pomocy jednego lub kilku biegłych, chyba że z okoliczności wyraźnie wynika, iż jest to bezużyteczne.

Sędzia może także odwołać się do pomocy biegłych w sytuacjach, w których nie wymaga tego przepis prawa, ale według jego uzasadnionej oceny opinia eksperta jest konieczna. Nominowanie biegłych lub przyjęcie relacji wykonanych przez innych biegłych jest obowiązkiem sędziego. Może on uczynić to $\mathrm{z}$ własnej inicjatywy bądź

\footnotetext{
${ }^{80}$ Por. Franciszek, Mitis Iudex Dominus Iesus, s. 19, kan. 1674, $\$ 1$.

${ }^{81}$ Por. KPK/83, kan. 1430-1431

${ }^{82}$ Por. R. Sztychmiler, Podmioty obowiązku ustalenia prawdy..., s. 90.

${ }^{83}$ Por. J. Soкоєowski, Sprawy o stwierdzenie nieważności małżeństwa z udziałem biegłych, Prawo Kanoniczne 56(2013) nr 4, s. 102.

${ }^{84} \mathrm{KPK} / 83$, kan. 1574.

${ }^{85}$ Por. Franciszek, Mitis Iudex Dominus Iesus, s. 23, kan. $1678 \$ 3$.
} 
na wniosek stron ${ }^{86}$. Przygotowanie opinii przez biegłego jest formą współpracy z sędzią, który dekretem określa zagadnienia wymagające opinii eksperta, a po jej przedstawieniu dokonuje jej krytycznej oceny. Ważne jest, aby biegły w swojej ekspertyzie uwzględniał nauczanie Kościoła w kwestiach dotyczących małżeństwa oraz zasady antropologii chrześcijańskiej ${ }^{87}$.

Podsumowując powyższe rozważania należy stwierdzić, że w procesie o stwierdzenie nieważności małżeństwa zadanie poszukiwania prawdy obiektywnej spoczywa nie tylko na osobie sędziego, ale również na wszystkich uczestnikach procesu. Wszystko to potwierdza, że prawodawca, zarówno w przepisach kodeksowych dotyczących procesu o orzeczenie nieważności małżeństwa, w Instrukcji Dignitas Connubii, jak i w najnowszym motu proprio Mitis Iudex Dominus Iesus zawarł zasadę poszukiwania prawdy obiektywnej jako jedną $\mathrm{z}$ naczelnych zasad.

\section{Adwokat współpracownikiem sędziego w poszukiwaniu prawdy obiektywnej na poszczególnych etapach procesu o orzeczenie nieważności małżeństwa}

Każdy wierny ma prawo do pełnego korzystania z uprawnień wynikających $\mathrm{z}$ przepisów prawa kanonicznego, w tym $\mathrm{z}$ prawa do obrony. Zgodnie z KPK/83 wiernym „przysługuje legalne dochodzenie i obrona uprawnień" 88 i mają oni prawo „być sądzeni z zachowaniem przepisów prawa, stosowanych ze słusznością"89. Prawodawca kościelny jednoznacznie wskazuje więc na konieczność przestrzegania przepisów procesowych dla pełnego zabezpieczenia oraz możliwości praktycznej realizacji fundamentalnego prawa wiernych w Kościele, jakim jest prawo do obrony. „Nad zachowaniem tych przepisów czuwał będzie zawsze adwokat, jako ten, który jawi się jako - jeśli nie

\footnotetext{
${ }^{86} \mathrm{KPK} / 83$, kan. 1575; DC, art. $203 \$ 2$.

${ }^{87}$ Por. M. Kowalski, Problem nieważności małżeństwa w świetle kanonu 1095 n. 2 KPK, Wrocław 2012, s. 263-265.

${ }^{88} \mathrm{KPK} / 83$, kan. $221 \$ 1$.

${ }^{89} \mathrm{KPK} / 83$, kan. $221 \$ 2$.
} 
zawsze konieczny - to bardzo potrzebny, gwarant zachowania w sposób integralny prawa wiernych do obrony w procesach kanonicznych w ogólności, a w procesach małżeńskich w sposób szczególny"90.

Zgodnie z art. $113 \$ 1$ Dignitas Connubii „przy każdym sądzie powinien być urząd albo osoba, aby każdy mógł swobodnie i szybko uzyskać poradę dotyczącą możliwości i sposobu postępowania zmierzającego, jeśli to okazuje się możliwe, do wprowadzenia swojej sprawy o nieważność małżeństwa”. Zadanie to może być zlecone adwokatowi $^{91}$, a zatem już na etapie przedprocesowym ma on możliwość świadczenia pomocy potencjalnym stronom procesowym w dochodzeniu do poznania prawdy co do ewentualnej nieważności ich małżeństwa. Zgodnie z zasadami proceduralnymi określonymi w artykułach 2-5 motu proprio Mitis Iudex Dominus Iesus badanie przedprocesowe czyli duszpasterskie odbywające się w strukturach parafialnych lub diecezjalnych dla wiernych poddających w wątpliwość ważność ich małżeństwa, także w pewnych okolicznościach może zostać powierzone adwokatowi. W każdym zaś przypadku można mu zlecić, na podstawie materiału zgromadzonego w czasie badania duszpasterskiego - jeśli jest taka potrzeba - sporządzenie skargi celem złożenia jej we właściwym trybunale ${ }^{92}$.

\subsection{Proces małżeński zwykły przed trybunałem}

W samym procesie o stwierdzenie nieważności małżeństwa udział adwokata jest wprawdzie fakultatywny ${ }^{93}$, ale strony mogą w sposób

\footnotetext{
${ }^{90}$ A. G. Miziński, UdZią adWOKATA W KANONICZNYCH PROCESACH MA£ŻEŃSKICH, w: Rodzina w prawie. Księga pamiątkowa dedykowana ks. prof. dr. hab. Ryszardowi Sztychmilerowi z okazji 65. rocznicy urodzin i 30-lecia pracy naukowej”, red. M. Różański, J. Krzywkowska, Olsztyn 2013, s. 66; por. A. G. Miziński, Adwokat kościelny w aktualnych przepisach prawa kanonicznego, Teka Komisji Prawnej-OL PAN 5(2012), s. 102.

${ }^{91}$ DC, art. $113 \$ 4$.

92 Por. Franciszek, Mitis Iudex Dominus Iesus, s. 37, art. 5.

${ }^{93}$ Zob. szerzej A. G. Miziński, Status prawny adwokata..., s. 270-275; J. KRzYwKowska, Skarga powodowa o nieważność małżeństwa. Wymogi materialne i formalne, Kościół i Prawo 3(16) 2014 nr 2, s. 162.
} 
wolny skorzystać z jego pomocy. Ponadto sędzia, widząc poziom trudności poszczególnych przypadków albo też pewną niezdolność lub niezaradność stron procesowych, może podjąć decyzję o konieczności ustanowienia dla nich pełnomocnika lub/i adwokata ${ }^{94}$. Co więcej, aby skutecznie zabezpieczyć prawa stron procesowych, może on skorzystać z tego uprawnienia i ustanowić adwokata nawet niezależnie od ich woli ${ }^{95}$. Adwokat powinien działać przede wszystkim w interesie strony, której jest obrońcą, jednakże nigdy nie może stracić z pola widzenia prawdy, którą należy odkrywać w postępowaniu procesowym kierując się zawsze zasadą sprawiedliwości ${ }^{96}$. W ten sposób sędzia zyskuje współpracownika, który, podobnie jak on sam, będzie troszczył się o ustalenie prawdy o przedmiocie sporu oraz pomoże mu osiągnąć pewność moralną co do rozstrzygnięcia danej sprawy. Zasada prawdy obiektywnej nie odnosi się bowiem jedynie do sędziego, ale domaga się współpracy wszystkich tworzących trybunał i świadczących mu pomoc ${ }^{97}$, o czym była mowa już wcześniej.

Rola adwokata kościelnego uwidacznia się w działaniach podejmowanych przez niego na poszczególnych etapach procesu, a jego uczestnictwo $\mathrm{w}$ procesie $\mathrm{w}$ naturalny sposób dynamizuje wszczęte postępowanie sądowe. Poprzez czuwanie nad dopełnieniem wszystkich formalnych wymogów przez stronę, której interesów broni, adwokat przyczynia się do sprawniejszego przebiegu całego procesu. W trakcie postępowania procesowego zadanie adwokata polega

\footnotetext{
${ }^{94}$ Por. KPK/83, kan. $1481 \$ 1$.

${ }^{95}$ Por. DC, art. $101 \$ 2$; Por. W. Kiwion, Strony procesowe, w: Komentarz do Instrukcji procesowej «Dignitas connubii», red. T. Rozkrut, Sandomierz 2007, s. 162 163; R. Sztychmiler, Znaczenie udziału adwokata $w$ kanonicznych procesach małżeńskich, w: Problemy z sądową ochroną praw człowieka, red. R. Sztychmiler, J. Krzywkowska, Olsztyn 2012, t. 1, s. 58-59.

${ }^{96}$ Por. M. Musselli, Il ministero degli avvocati tra difesa del cliente e fedeltà alla verità e alla giustizia, w: AA.VV., La giustizia nella Chiesa: fondamento divino e cultura processualistica moderna, Città del Vaticano 1997, s. 147-163.

${ }^{97}$ Por. A. G. Mizıński, Prawo wiernych do obrony w procesie kanonicznym, Teka Komisji Prawnej - OL PAN, 2(2009), s. 80.
} 
przede wszystkim na wspieraniu strony w sprecyzowaniu przedmiotu i podstawy prawnej sporu, a także w uwydatnieniu okoliczności faktu spornego.

Koniecznym warunkiem formalnego przyjęcia sprawy przez sędziego i rozpoczęcia każdego procesu, także ustnego, jest złożenie przez stronę, zasadniczo na piśmie, skargi powodowej ${ }^{98}$. Na tym etapie adwokat pomaga sędziemu w poznaniu podstawowych faktów prawnych poprzez dopilnowanie, aby skarga zawierała informacje odnośnie do stron i przedmiotu sporu oraz określenie prawa, na którym strona opiera swoje roszczenie ${ }^{99}$. Ponadto może zasugerować stronie dołączenie do skargi dokumentów ułatwiających rozpoznanie sporu, jak na przykład pisemne oświadczenie głównych świadków, świadectw lekarskich, itd. ${ }^{100}$ Należy podkreślić, że w zależności od późniejszej pozycji procesowej, adwokat może służyć stronie jedynie pomocą w redagowaniu skargi powodowej lub też, występując $\mathrm{w}$ roli pełnomocnika strony, być autorem skargi ${ }^{101}$ i złożyć ją w odpowiednim trybunale wraz $z$ autentycznym zleceniem ${ }^{102}$. Nie ulega wątpliwości, że dobrze zredagowana i prawidłowo złożona skarga powodowa ma większe szanse, że zostanie przez sędziego przyjęta ${ }^{103}$ $\mathrm{i}$ będzie pomocą $\mathrm{w}$ dotarciu do prawdy materialnej.

Niezmiernie istotne dla dotarcia do prawdy są działania adwokata na etapie dowodowym procesu - redaguje on pisma procesowe

${ }^{98}$ Por. KPK/83, kan. 1501: „Sędzia nie może rozpoznawać żadnej sprawy, jeżeli ten, kto jest zainteresowany, albo rzecznik sprawiedliwości nie przedstawi prośby zgodnie z przepisami kanonów”. Skarga powodowa, nazywana czasem prośbą lub rekursem - w postępowaniu sporno-administracyjnym - zawsze jest wymagana do rozpoczęcia procesu. W can. 1620, n. 4 prawodawca stwierdza, że proces nie może być prowadzony bez skargi sądowej, a gdyby był w taki sposób prowadzony, wydany wyrok byłby dotknięty wadą nieważności nieusuwalnej; por. DC, art. 114; R. Sztrchmiler, Proces sporny, w: Komentarz do Kodeksu Prawa Kanonicznego, t. 5, red. J. Krukowski, G. Erlebach, A. Dzięga, R. Sztychmiler, Poznań 2007, s. 128.

${ }^{99}$ Por. R. Sztychmiler, Znaczenie udziału adwokata w kanonicznych..., s. 60.

${ }^{100}$ Por. A. G. Miziński, Status prawny adwokata..., s. 384-385.

${ }^{101}$ Por. A. G. Miziński, Udział adwokata..., s. 61.

${ }^{102}$ Por. A. G. Miziński, Status prawny adwokata..., s. 386.

${ }^{103}$ Por. tamże, s. 387. 
kierowane do sądu, wskazuje stronie na przysługujące jej prawa do zgłaszania ekscepcji, nowych świadków bądź wniosków, pilnuje dotrzymania przez stronę terminów sądowych. Ma on możliwość przedstawiania dowodów jakiegokolwiek rodzaju, które - zgodnie ze wskazaniem zawartym w kan. $1527 \$ 1$, „wydają się pożyteczne do poznania sprawy i są godziwe"104. Trzeba jednak pamiętać, że sędziemu należy przedłożyć taką ilość środków dowodowych, by on sam nie musiał ich uzupełniać, mimo iż kan. $1452 \$ 2$ przewiduje taką możliwość. Zadaniem adwokata jest więc wybór, zgłoszenie i odpowiednie przedstawienie środków dowodowych, które, uzasadniając pewność, uczciwość oraz wiarygodność prezentowanych faktów, pozwolą sędziemu na wykluczenie jakiejkolwiek rozumnej wątpliwości co do prawdy, a zatem umożliwią osiągnięcie pewności moralnej obiektywnej ${ }^{105}$.

W tym co odnosi się do dowodu ze świadków, nawet jeśli osobą odpowiedzialną za jego przeprowadzenie jest sędzia, to adwokat troszczy się o ich stawiennictwo oraz może wskazać te kwestie, które w sposób istotny przyczynią się do rozstrzygnięcia sprawy. Zgodnie z kan. 1559 KPK/83: „Strony nie mogą być obecne przy zeznaniach świadków, chyba że sędzia, zwłaszcza gdy sprawa dotyczy dobra prywatnego, uzna że trzeba je dopuścić". Prawodawca zezwala natomiast na obecność ich adwokatów lub pełnomocników podczas przesłuchania stron, świadków i biegłych, chyba że w opinii sędziego, z powodu okoliczności, rzeczy i osób, postępowanie powinno być przeprowadzone $\mathrm{z}$ zachowaniem tajemnicy ${ }^{106}$. Decyzja o wyłączeniu adwokata z przesłuchania musi być jednak oparta na poważnych przyczynach. Udział adwokata w przesłuchaniu stron, świadków i biegłych w procesie o stwierdzenie nieważności małżeństwa został uregulowany

\footnotetext{
${ }^{104}$ Odnośnie do procesów o stwierdzenie nieważności małżeństwa por. DC, art. $157 \$ 1$.

${ }^{105}$ Por. Z. Grocholewski, Pewność moralna jako klucz do lektury norm procesowych, Jus Matrimoniale 9(1998), s. 26.

${ }^{106}$ Por. KPK/83, kan. 1559; R. SzTYCHMILER, Znaczenie udziału adwokata w kanonicznych..., s. 63.
} 
w kan. $1677 \S 1 \mathrm{nr} 1$ motu proprio Mitis Iudex Dominus Iesus, a także art. $159 \$ 1$ DC. Obecność przy przesłuchaniu świadków to możliwość aktywnego udziału adwokata w postępowaniu, co może mieć wpływ na jego skuteczniejsze działanie ${ }^{107}$. Aktualne przepisy nie określają sposobu, w jaki należy przeprowadzić posiedzenie sądowe $\mathrm{z}$ udziałem adwokatów, stron i świadków. W tym co odnosi się do zadawania pytań osobie zeznającej, adwokaci mogą je stawiać tylko za pośrednictwem sędziego, chyba że prawo partykularne zastrzega inaczej ${ }^{108}$.

Jeśli, na podstawie nakazu prawa lub sędziego, zachodzi konieczność powołania biegłego sądowego, adwokat ma prawo do weryfikacji jego kwalifikacji ${ }^{109}$. Może on także na wniosek strony powołać biegłego prywatnego ${ }^{110}$, nawet jeśli sędzia nie widzi takiej konieczności. Ma również prawo prosić sędziego (przewodniczącego lub ponensa) o dopuszczenie opinii pozaprocesowych wydanych przez innych biegłych ${ }^{111}$. Adwokat, wykorzystując swoją biegłość w prawie, może zwrócić uwagę na te kwestie, które nie zostały dostrzeżone przez sędziego, strony i innych uczestników procesu, a które dla przeprowadzenia postępowania sądowego są ważne i wymagają opinii specjalisty.

Nie mniej ważnym obowiązkiem adwokata na etapie dowodowym jest czuwanie nad przestrzeganiem terminów w przedkładaniu środków dowodowych zarówno przez stronę, jak i samego sędziego oraz zwracanie uwagi na ewentualne nadużycia ${ }^{112}$. Wszystko to przyczynia

\footnotetext{
${ }^{107}$ Por. T. Rozkrut, Dowody, w: Komentarz do Instrukcji procesowej «Dignitas connubii», red. T. Rozkrut, Sandomierz 2007, s. 235-236.

${ }^{108}$ Por. KPK/83, kan. 1533, 1561, 1564.

${ }^{109}$ Por. Franciszek, Mitis Iudex Dominus Iesus, s. 23, kan. $1678 \$ 3 ;$ KPK/83, kan. 1574; R. SzTychmiler, Zadania adwokata zwiazane z udziałem biegłych w procesie o nieważność małżeństwa, w: Zalety oraz wady kanonicznego procesu o stwierdzenie nieważności małżeństwa. Materiały z ogólnopolskiego spotkania pracowników sadownictwa kościelnego w Gródku nad Dunajcem w dniach 13-14 czerwca 2011 roku, red. T. Rozkrut, Tarnów 2012, s. 147-155.

${ }^{110}$ Por. DC, art. $213 \$ 1-2$.

${ }^{111}$ Por. KPK/83, kan. 1575; DC, art. $204 \$ 1$.

112 Por. A. G. Miziński, Status prawny adwokata..., s. 396.
} 
się do zobiektywizowania badań i pomaga w dotarciu do poznania prawdy i uzyskania przez sędziego pewności moralnej co do rozstrzygnięcia przedłożonej mu sprawy ${ }^{113}$.

Prawodawca w kan. $1598 \$ 1 \mathrm{KPK} / 83$ gwarantuje stronom możliwość zapoznania się z aktami sprawy przed zamknięciem postępowania dowodowego. Zgodnie $\mathrm{z}$ art. $134 \$ 1 \mathrm{DC}$ uprawnienie to jest tak naprawdę zapewnieniem minimum wspólnego dążenia stron do poznania prawdy o ich małżeństwie ${ }^{114}$. W wyżej wymienionych przepisach oraz w art. $229 \$ 3$ DC podkreśla się, że po zebraniu dowodów „sędzia, pod sankcją nieważności musi dekretem zezwolić stronom $\mathrm{i}$ ich adwokatom, aby w kancelarii trybunału przejrzeli akta, które nie są im jeszcze znane"115. W czasie publikacji akt adwokat ma prawo żądać i może otrzymać potrzebne odpisy akt sprawy ${ }^{116}$. Ponadto może on zapoznać się z dowodami przedkładanymi przez strony oraz przeglądać akta sądowe również w innych momentach procesu, także przed ich publikacją ${ }^{117}$.

Adwokat jawi się jako cooperator veritatis również na etapie dyskusji sprawy. Jego udział jest szczególnie widoczny w przypadku konieczności przeprowadzenia dyskusji ustnej wobec trybunału ${ }^{118}$. Praktyka sądowa wskazuje, że strony prywatne niekorzystające z pomocy adwokatów, bardzo często rezygnują z przysługującej im na tym etapie możliwości przedstawienia odpowiednich opinii i argumentacji. Skutkuje to tym, że strona, nie mając nic do dodania, zdaje się na sprawiedliwość trybunału. Adwokat reprezentujący stronę natomiast

\footnotetext{
${ }^{113}$ Por. tamże, s. 410.

${ }^{114}$ Por. J. Llobell, Cenni sul diritto di difesa alla luce dell'istr. "Dignitas connubii" w: AA.VV., Il diritto della difesa nel processo matrimoniale canonico, Città del Vaticano 2006, s. 72; A. PAstwa, Prawo do obrony i swobodnego dostępu do adwokata. Systemowe gwarancje realizacji praw podmiotowych stron $w$ procesie de nullitate matrimonii, Śląskie Studia Historyczno-Teologiczne 2008, t. 41, z. 1, s. 55.

${ }^{115}$ G. LeszczyńsKi, Gwarancje prawa do obrony w świetle instrukcji Dignitas Connubii, Studia Ełckie 12/2010, s. 259.

${ }^{116}$ Por. KPK/83, kan. $1598 \$ 1$.

${ }^{117}$ Por. R. Sztychmiler, Znaczenie udziału adwokata w kanonicznych..., s. 65.

${ }^{118}$ Por. KPK/83, kan. $1604 \$ 2$; DC, art. $244 \$ 1$.
} 
poucza ją o przysługujących jej w tym zakresie prawach i w toku dyskusji przedstawia dodatkowe, bardziej precyzyjne wyjaśnienie tych kwestii, które mogą pomóc sędziemu w dotarciu do prawdy i ostatecznym rozstrzygnięciu sprawy ${ }^{119}$. Ponieważ to obrona w zasadniczy sposób wskazuje na ostateczne stanowisko strony, pomoc adwokata na tym etapie wydaje się być nieodzowna. Strona, nie mając odpowiednich kwalifikacji prawnych, nie jest w stanie przedstawić wymaganej interpretacji prawnej i faktycznej akt procesowych ${ }^{120}$. Dlatego te $\dot{z}$ „wskazane byłoby, aby głosy obrończe przygotowywane były przez adwokatów, którzy dobrze znają przepisy prawne i potrafią umiejętnie zinterpretować poszczególne dowody"121. Kompetentne przygotowanie głosu obrończego przez adwokata pozwala na usystematyzowanie przedstawionych wcześniej faktów i dowodów, co byłoby trudne w przypadku podjęcia się osobistej obrony przez stronę, która ma bezpośredni interes w sprawie $\mathrm{i}$ jest w nią emocjonalnie zaangażowana, co może sukcesywnie skutkować subiektywną oceną niektórych faktów. Adwokat ma także prawo do zgłoszenia repliki na głos obrońcy strony przeciwnej lub obrońcy węzła. W dyskusji przedwyrokowej powinien on wyeksponować te punkty, które strona przedłożyła sądowi ${ }^{122}$. Powyższe czynności wskazują, że posługa adwokata jest dla sędziego dużym wsparciem w dążeniu do prawdy obiektywnej $^{123}$.

Adwokat nie bierze udziału w wydawaniu wyroku, gdyż czynność ta jest zarezerwowana dla sędziego ${ }^{124}$, ale rzetelne wykonywanie zadań w poprzedzających je fazach procesu przyczynia się do poznania przez sędziego faktów koniecznych do sprawiedliwego rozstrzygnięcia sporu.

\footnotetext{
${ }^{119}$ Por. A. G. Miziński, Status prawny adwokata..., s. 421.

${ }^{120}$ Por. M. J. Arroba Conde, Diritto processuale canonico, Roma 1993, s. 415.

${ }^{121}$ A. DzIĘGA, Kościelny proces ustny, Warszawa 1992, s. 168.

${ }^{122}$ Por. KPK/17, kan. $1866 \$ 2-3$.

${ }^{123}$ Por. R. Sztychmiler, Znaczenie udziału adwokata w kanonicznych..., s. 67.

${ }^{124}$ Por. KPK/83, kan. 1607; A. G. MizıŃski, Status prawny adwokata..., s. 428.
} 
Każdy wierny ma prawo do sprawiedliwego wyroku, wydanego zgodnie z przepisami prawa oraz z zachowaniem zasad sprawiedliwości i słuszności kanonicznej. Niespełnienie tych warunków może stanowić naruszenie prawa wiernego do obrony ${ }^{125}$. Dlatego też zadania adwokata nie kończą się w momencie publikacji wyroku. Już po tym fakcie może on podjąć działania w celu weryfikacji ewentualnych błędów w wyroku, które można i trzeba usunąć poprzez poprawę lub uzupełnienie dokonane przez trybunał. Adwokat może być pomocny również w przypadku, gdy strona stwierdzi, że czuje się skrzywdzona rozstrzygnięciem sędziego, które nie odpowiada prawdzie obiektywnej. Jego zadaniem będzie wtedy rozważenie możliwości zaskarżenia wyroku $^{126}$. Jeżeli więc, wskutek nieważności, niesprawiedliwości czy niesłuszności, wyrok okaże się wadliwy, adwokat, broniąc uprawnień strony, wskazuje jej możliwości zaskarżenia wyroku poprzez: skargę o jego nieważność, apelację, czy - w sprawach o stwierdzenie nieważności małżeństwa - novam causae propositio ${ }^{127}$.

Przepisy zawarte w KPK/83 oraz w Instrukcji Dignitas Connubii przewidują możliwość zaistnienia w czasie procesu sytuacji nietypowych, jak niestawiennictwo stron, zakończenie bądź zawieszenie instancji czy też sprawy wpadkowe, które mają wpływ na dalsze prowadzenie procesu ${ }^{128}$. Także w tych sytuacjach adwokat, dbając o zachowanie obowiązującego prawa, będzie się starał, aby uprawnienia strony były faktycznie realizowane, a nie pozostawały jedynie martwą literą prawa. Jako osoba kompetentna pod względem merytorycznym i znająca formalną stronę postępowania w tych określonych przypadkach będzie on pomagał stronie w podjęciu właściwych działań służących rozwiązaniu sprawy ${ }^{129}$.

\footnotetext{
${ }^{125}$ Por. A. G. MizıŃski, Udział adwokata..., s. 66.

${ }^{126}$ Por. A. G. Miziński, Status prawny adwokata..., s. 428-429.

${ }^{127}$ Por. KPK/83, kan. 1619-1648. Ponadto w sprawach małżeńskich: DC, art. 269-294.

${ }^{128}$ Por. DC, art. 217-228.

${ }^{129}$ Szerzej na ten temat zob. A. G. Miziński, Status prawny adwokata..., s. 449-462;

A. G. MizıŃski, Udział adwokata..., s. 64.
} 


\subsection{Proces małżeński skrócony przed biskupem}

Nowe przepisy dotyczące procesu o stwierdzenie nieważności małżeństwa zawarte w Liście apostolskim motu proprio „Mitis Iudex Dominus Iesus" dają możliwość skorzystania z procesu skróconego przed biskupem diecezjalnym. Możliwe jest to w przypadku gdy obydwoje małżonków prosi o to zgodnie lub jedno $\mathrm{z}$ nich prosi za zgodą drugiego a przytoczone fakty, osoby i okoliczności w sposób oczywisty wskazują na nieważność zaskarżonego małżeństwa ${ }^{130}$.

W tego rodzaju postępowaniu rola adwokata jako obrońcy strony i współpracownika sędziego w poszukiwaniu prawdy obiektywnej nabiera jeszcze większego znaczenia. Jest to widoczne już na etapie przygotowania skargi powodowej, w której, oprócz elementów wymienionych w kan. $1504 \mathrm{KPK} / 83$, powinny być krótko, ale jasno i całościowo przedstawione fakty, na których opiera się prośba o proces skrócony, wskazane „dowody, które mogłyby być natychmiast zebrane przez sędziego" oraz załączone dokumenty uzasadniające prośbę ${ }^{131}$. Po określeniu formuły wątpliwości wikariusz sądowy „,wzywa wszystkich, którzy powinni wziąć udział na posiedzenie"132. Takie sformułowanie wskazuje raczej na możliwość obecności adwokata na tymże posiedzeniu, w czasie którego pod przewodnictwem instruktora zbierane będą dowody i wyznaczony zostanie termin przedstawienia wniosków obrończych stron. Zadaniem adwokata będzie także przygotowanie na rzecz strony głosu obrończego, zawierającego środki dowodowe przemawiające za nieważnością małżeństwa ${ }^{133}$.

W przypadku wydania przez biskupa diecezjalnego wyroku stwierdzającego nieważność małżeństwa, jeśli jedna ze stron decyduje się na zaskarżenie wyroku, adwokat będący jej obrońcą ma prawo wniesienia apelacji „do metropolity lub do Roty Rzymskiej; jeżeli wyrok został wydany przez metropolitę, przysługuje apelacja do najstarszego sufragana; od wyroku innego biskupa, który nie ma

\footnotetext{
${ }^{130}$ Por. Franciszek, Mitis Iudex Dominus Iesus, s. 27, art. 5, kan. 1683.

${ }^{131}$ Por. tamże, s. 27, art. 5, kan. 1684.

${ }^{132}$ Tamże, s. 29, art. 5, kan. 1685.

${ }^{133}$ Por. tamże s. 29, art. 5, kan. 1686.
} 
zwierzchnika niższego niż Biskup rzymski, przysługuje apelacja do

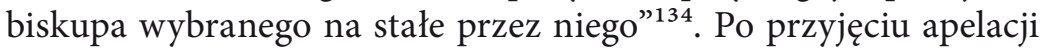
sprawa zostaje rozstrzygnięta w trybie procesu zwykłego, w którym adwokat spełnia swoje zadania w sposób przewidziany dla pierwszej instancji, co zostało przedstawione powyżej. Taka sama sytuacja ma miejsce w przypadku, gdy biskup diecezjalny na podstawie przedstawionych mu akt sprawy, po konsultacji z instruktorem i asesorem oraz rozważeniu uwag obrońcy węzła i wniosków obrończych, nie osiągnął pewności moralnej co do nieważności małżeństwa, przekazuje sprawę do procesu zwykłego ${ }^{135}$.

Reasumując, adwokat broni interesów strony, która poprosiła go o pomoc poprzez podejmowanie działań na różnych etapach procesu i, mając na względzie wygranie sprawy, może wykazać się znacznym stopniem zaangażowania. Musi jednak pamiętać, że w trakcie procesu „nie powinien wyłączać się z jedynego i wspólnego celu końcowego, jakim jest poszukiwanie, odkrywanie i prawomocne potwierdzanie prawdy, a więc faktu obiektywnego" ${ }^{136}$.

\section{Zakończenie}

Podsumowując powyższe rozważania należy stwierdzić, że mimo iż pierwszym i zasadniczym zadaniem adwokata jest obrona interesów strony procesowej to $\mathrm{w}$ tym szczególnym procesie jakim jest proces o stwierdzenie nieważności małżeństwa nie mniej ważnym zadaniem adwokata jest aktywna współpraca $\mathrm{z}$ innymi uczestnikami procesu, w sposób szczególny z sędzią (biskupem diecezjalnym), mająca na celu poznanie prawdy obiektywnej na temat waloru prawnego węzła małżeńskiego na tyle, by sędzia mógł uzyskać pewność moralną co do jego nieważności i w oparciu o nią wydać wyrok rozstrzygający sprawę definitywnie. Konieczność współpracy w celu poznania prawdy obiektywnej wynika z jednej strony z publicznej natury małżeństwa, a co za tym idzie z publicznego charakteru procesu (zwykłego lub skróconego

\footnotetext{
134 Tamże, s. 29, art. 5, kan. $1687 \$ 3$.

${ }^{135}$ Por. tamże, s. 29, art. 5, kan. $1687 \$ 1$.

${ }^{136}$ W. Gór ALSKI, Rola i zadania adwokata..., s. 110-111.
} 
przed biskupem) o stwierdzenie nieważności małżeństwa, $\mathrm{z}$ drugiej zaś z nadrzędnej zasady poszukiwania prawdy obiektywnej w tego typu procesie. Wszystkie czynności podejmowane przez adwokata zarówno na etapie przedprocesowym, jak i w czasie trwania procesu, oprócz obrony uprawnień strony służą temu nadrzędnemu celowi. Jego osiągnięcie może domagać się czasami wniesienia, z upoważnienia strony procesowej, środków zaskarżających wyrok rozstrzygający sprawę. Wszystko to daje podstawy, by jednoznacznie stwierdzić iż adwokat, nie przestając być obrońcą, jest także współpracownikiem sędziego w poszukiwaniu prawdy.

\section{Advocate - cooperator veritatis in the process of the nullity of marriage}

An advocate is a qualified person who meets the requirements specified in can. $1483 \mathrm{CIC} / 83$, recognized by the competent authority, who was asked by a party to the process for personal assistance, involving the defense of the interests of the client in the process or defense in court. The task of the advocate in the law of the Latin Church was defined by the term munus and officium of an ecclesiastical nature. The advocate always acts taking into account the spirit and the objectives of the canon legal order, and therefore, like other participants of the process, is obligated to cooperate with the judge in the realisation of the fundamental purpose of proceedings under canon law, which is the search for the objective truth.

One of the guiding principles in the process of matrimonial nullity contained in motu proprio Mitis Iudex Dominus Iesus, the Code of Canon Law and the Instruction Dignitas Connubii is the principle of seeking the objective truth. To implement this principle, cooperation is required of all participants in the process, so a judge (the diocesan bishop in an abbreviated process), the parties, the defender of the marriage bond, the advocate and the promoter of justice - if he takes part in it.

A special role in this cooperation is played by the advocate, who as a person competent and skilled in law will help the judge in achieving the moral certitude needed to adjudicate on a case by presenting to him already structured facts and proofs that allow him to pass an equitable judgment. Throughout the duration of the case, ranging from assistance still before 
the start of the trial (ordinary or abbreviated), through lodging a libellus of litigation, actions during the trial itself and after a verdict, the advocate is - even if not always necessary - a very helpful guarantor of the faithful's right to defense. In performing his task the advocate should act primarily in the interests of the party that he is defending, but never lose sight of the truth, which should be discovered in judicial proceedings always guided by the principle of justice.

SŁOWA KLUCZOWE: adwokat, proces, prawda obiektywna, prawo do obrony.

KEY wORDs: advocate, process, objective truth, the right to defense.

\section{Nota o Autorze:}

BP DR HAB. ARTUR G. Miziński - Jest pracownikiem naukowym WPPKiA KUL. W 2012 r. otrzymał stopień doktora habilitowanego z zakresu prawa kanonicznego. Jest autorem kilkudziesięciu publikacji z zakresu kościelnego prawa karnego materialnego, kościelnego procesu karnego oraz postępowania administracyjnego. Jest członkiem Towarzystwa Naukowego KUL; Stowarzyszenia Kanonistów Polskich; Komisji XIV Prawniczej Oddziału PAN w Lublinie; rady naukowej czasopisma „Kościół i Prawo”. Jest biskupem pomocniczym Archidiecezji Lubelskiej i Sekretarzem Generalnym KEP. 